\title{
ПІДГОТОВКА НАУКОВО-ПЕДАГОГІЧНИХ ПРАЦІВНИКІВ ДО ДІЯЛЬНОСТІ У НЕФОРМАЛЬНІЙ ОСВІТІ ДОРОСЛИХ: РЕАЛІЇ ТА ПЕРСПЕКТИВИ
}

У статті схарактеризовано сутність, сочіальну і культурну значимість, особливості і провідні функиії сучасної неформальної освіти дорослих.

Обтрунтовано перспективи вирішення проблеми забезпечення неформальної освіти дорослих професійними кадрами завдяки організаиії спеціальної фахової підготовки майбутніх науковопедагогічних працівників в умовах магістратури закладів вищої освіти.

Ключові слова: неформальна освіта дорослих, науково-педагогічні працівники, освітньо-професійні програми.

Постановка проблеми у загальному вигляді та її зв'язок із важливими науковими і практичними завданнями. Тривалий час українська неформальна освіта дорослих лишалася поза предметом дослідження науковцями, не була ноуменом, не осягалася розумом і не становила основу інтелектуального споглядання. Але досвід іiї існування і стрімкого просування в українському освітньому просторі дорослих вимагає приділити феномену активного розвитку цього явища спеціальну увагу.

Метою неформальної освіти дорослих є реалізація права дорослої людини на освіту протягом життя, активне іï включення в професійне і суспільне життя через отримання необхідних і раціональних відповідних освітніх послуг. Такі послуги надають громадянські колективи різного рівня - державного, конфесійного, професійного чи іншого, корпоративні суб’єкти, приватні індивіди та їхні родини, які мають юридичне право на надання таких освітніх послуг в Україні. Базова освіта і кваліфікаційні характеристики надавачів послуг неформальної освіти дорослих часто не відповідають вимогам, які висуваються до педагогічних і науково-педагогічних працівників офіційних закладів освіти. Водночас, питання специфіки змісту і організації фахової діяльності педагогічних i науково-педагогічних працівників в умовах неформальної освіти дорослих досліджені недостатньо.

Аналіз основних досліджень і публікацій із зазначеної проблеми. Педагогічною діяльністю можуть займатися особи з високими моральними якостями, які мають відповідну освіту і професійнопрактичну підготовку. Педагогічну діяльність у закладах освіти здійснюють педагогічні працівники, у вищих закладах освіти третього і четвертого рівнів акредитації та закладах післядипломної освіти науково-педагогічні працівники. Невизначеними залишаються питання здійснення педагогічної діяльності з дорослими, особливо в умовах неформальної освіти.

Важливе значення для розвитку неформальної освіти дорослих в Україні мають дослідження неформальної освіти різних спільнот і категорій дорослого населення в зарубіжних країнах вчених Н. Бідюк, Е. Богів, В. Давидова, Т. Десятова, О. Зюнькіної, О. Жижко, А. Каплуна, С. Коваленко, О. Огієнко, Н. Пазюри, І. Сагун, М. Сісей, С. Синенко, І. Фольварочного, Ю. Шустак та ін. Тема неформальної освіти дорослих в Україні порушена також у працях Л. Вовк, О. Друганової,

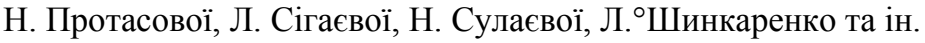

Значний науковий інтерес для українських практиків сфери неформальної освіти дорослих представляють дослідження сучасних вчених-дослідників освіти дорослих О. Аніщенко, О. Дубасенюк, Л. Лук'янової, Н. Нічкало, О. Пехоти, Т. Сорочан та ін.

Особливості професійної діяльності фахівців, які навчають дорослих (андрагогів), як психологопедагогічна проблема, знаходяться у полі зору білоруських і російських вчених Л. Бендова, Н. Бичкова, Н. Букіна, Т. Галкіна, М. Громкова, С. Невдах, В. Подобєд, О. Ройтблат, О. Соколова, І. Скриннік, І. Тікушина, Л. Устич, М. Якушкина та ін.

Окреслення невирішених питань, порушених у статті. Аналіз педагогічної літератури i дисертаційних досліджень дозволив визначитися, що проблема розвитку неформальної освіти в Україні не була предметом системного вивчення й спеціального аналізу, у тому числі й відносно підготовки педагогічних і науково-педагогічних працівників до фахової діяльності в умовах неформальної освіти дорослих.

Метою статті є окреслити зазначену проблему і проаналізувати реалії і перспективи підготовки майбутніх науково-педагогічних працівників до фахової діяльності в умовах неформальної освіти дорослих.

Виклад основного матеріалу з обгрунтуванням отриманих наукових результатів. Неформальна освіта дорослих сьогодні є освітньою діяльністю, здійснюваною, як правило, за рамками офіційної 
(формальної) системи, не підкріплена дипломом офіційного зразка, розрахована на вмотивованих до навчання дорослих, що проводиться за освітніми програмами і темами, у визначені терміни, відповідає цілям навчання дорослих, забезпечує особистісно, професійно, соціально значущий результат [1: 209]

У сучасних українських умовах неформальна освіта дорослих має важливу соціальну і культурну значимість у вирішенні проблем гуманізації, духовності, толерантності, демократизації суспільних стосунків. Переорієнтація суспільних цінностей української спільноти триває. Окремі 3 них стають вимогою до освітніх процесів. Подолання авторитаризму, набуття гнучкості і мобільності, оволодіння моделями соціального партнерства тощо потребують створення спеціальних тренувальних і практичних освітніх майданчиків для дорослих 3 метою оволодіння цим усім на рівні конкретних дій. Успіх реалізації і впровадження вказаних функцій у масову практику в значній мірі залежить від володіння викладачами вузів андрагогічною моделлю освіти, яка засвоюється випускниками закладів вищої освіти, підготовлених до педагогічної діяльності з дорослими людьми, і здатних вміло тиражувати їі, поєднуючи наукову теорію і освітню практику.

Дослідження сучасного стану неформальної української освіти дорослих показало, що з їі допомогою вирішуються конкретні соціальні завдання на різних рівнях соціуму - особистість, сім'я, група, колектив, спільнота, суспільство, соціум. Неформальна освіта дорослих $є$ механізмом ефективних соціальних перетворень. Функціями неформальної освіти дорослих є: адаптаційна, інформаційна, компенсаторна, аналітична, розвивально-діяльнісна. Адаптаційна функція обгрунтована як набуття самостійності у пристосуванні до нових вимог життя та відповідальності за власну життєдіяльність і життєдіяльність найближчого соціуму; інформаційна функція полягає не тільки у можливостях оперувати і відтворювати інформацію, а й продукувати власну в процесі іï осмислення, структурування і генерування; компенсаторна як поновлення освітніх можливостей, які раніше були відсутні або зовсім втрачені; аналітична як дослідження та аналіз факторів, що впливають на реальні освітні потреби дорослих протягом життя; розвивально-діяльнісна функція означає гармонійний розвиток власних ключових компетентностей через оволодіння способами особистісної, соціокультурної, інтелектуальної, загальнопрофесійної діяльності.

Практика неформальної освіти показує, що готують, підвищують кваліфікацію, здійснюють перепідготовку, ведуть різноманітні курси, лекції, програми, тренінги, заходи задля задоволення низки пізнавальних, особистісних, соціальних, професійних потреб дорослих переважно громадські організації і приватні юридичні та фізичні особи, які мають право на надання освітніх послуг, рідше - наукові, науково-методичні, методичні установи, науково-виробничі підприємства, інформаційні служби офіційної (формальної) освіти.

Підготовку професійних кадрів, які б виконували педагогічну діяльність в неформальній освіті дорослих, здійснюють переважно неформальні освітні суб’єкти, оскільки в офіційному "Переліку посад педагогічних та науково-педагогічних працівників", затвердженому Постановою Кабінету Міністрів України № 963 від 14 червня 2000 р. [2] жодна з професій напряму не вказує на здійснення педагогічної діяльності в неформальній освіті дорослих чи взагалі в освіті дорослих.

Нами проаналізований чинний "Класифікатор професій ДК 003:2010", затверджений наказом Держспоживстандарту України від 28 липня 2010 р. № 327 [3] з метою виявлення офіційних професій, які могли обіймати фахівці, здійснюючи педагогічну діяльність 3 дорослими у неформальній освіті. У Розділі 2. "Професіонали" [3], який вміщує професії, що передбачають високий рівень знань у галузі фізичних, математичних, технічних, біологічних, агрономічних, медичних чи гуманітарних наук, до таких професій можна віднести позиції: викладачі університетів та вищих навчальних закладів; професіонали в галузі методів навчання; інші професіонали в галузі навчання; професіонали, що не входять в інші класифікаційні угруповання. У "Покажчику професійних назв робіт за кодами професій" до таких назв можна віднести: викладач вищого навчального закладу; консультант з питань здорового способу життя; науковий співробітник-консультант (в інших галузях навчання); інструктор навчальнотренувального центру; лектор.

У Розділі 3. "Фахівці" [3], який вміщує професії, що вимагають знань в одній чи більше галузях природознавчих, технічних і гуманітарних наук, у класифікації професій можна виокремити: фахівці в галузі освіти; інші фахівці в галузі освіти, а у "Покажчику професійних назв робіт за кодами професій": асистент вчителя; викладач-стажист; майстер навчального центру; педагог професійного навчання; інструктор культурно-просвітнього закладу.

Проблема підготовки науково-педагогічних кадрів до педагогічно-викладацької діяльності у неформальній освіті дорослих зумовлена також і відсутністю спеціально організованої підготовки майбутніх науково-педагогічних працівників у межах магістратури до такої фахової діяльності. У наукових i, навіть, нормативно-законодавчих джерелах існують різні підходи до визначення поняття "науково-педагогічний працівник" та сутності його фахової діяльності. Відповідно до П. 25. Ст. 1. Р. 1. Закону України "Про наукову і науково-технічну діяльність" науково-педагогічним працівником є вчений, який має вищу освіту не нижче другого (магістерського) рівня, відповідно до трудового договору 
(контракту) в університеті, академії, інституті професійно провадить педагогічну та наукову або науковопедагогічну діяльність та має відповідну кваліфікацію незалежно від наявності наукового ступеня або вченого звання, підтверджену результатами атестації у випадках, визначених законодавством.

Майбутніх науково-педагогічних працівників закладів та установ вищої освіти готують у закладах вищої освіти за освітньо-педагогічними програмами другого (магістерського) рівня вищої освіти у галузі знань "01 Освіта" за спеціальністю "011 Освітні, педагогічні науки" або "Науки про освіту" та "015 Професійна освіта (за спеціалізаціями)" спеціалізацією "Педагогіка вищої школи" 3 майбутньою кваліфікацією "Викладач університетів та вищих навчальних закладів". Такі освітні програми підготовки фахівців другого (магістерського) рівня вищої освіти розробляють відповідно до Закону України "Про вищу освіту" від 01.07.2014 р. № 1556-VII, Постанови Кабінету Міністрів України від 29.04.2015 № 266 "Про затвердження переліку галузей знань і спеціальностей, за якими здійснюється підготовка здобувачів вищої освіти", інших нормативних чинних постанов, наказів та відповідних методичних рекомендацій. Освітньо-професійні програми визначають основний фокус навчання, необхідний для здобуття магістерського рівня вищої освіти, перелік загальних та спеціальних (фахових) компетентностей, нормативний і варіативний зміст підготовки фахівця, сформульований у термінах результатів навчання, та вимоги до контролю якості вищої освіти.

Освітньо-професійні програми другого (магістерського) рівня вищої освіти у галузі знань "01 Освіта" за спеціальністю "011 Науки про освіту" і "015 Професійна освіта" із спеціалізацією "Педагогіка вищої школи", розроблені 16 закладами вищої освіти 2016-2018 навчальних років, які знаходяться у публічному доступі на сайтах цих вишів, і вибрані нами у довільному порядку, послугували підставою для аналізу сучасного стану підготовки майбутніх науково-педагогічних працівників до освітньої діяльності з дорослими за такими показниками: кваліфікація, яка присвоюється; мета і основний фокус програми та спеціалізації; придатність випускників до подальшого працевлаштування; вибіркові навчальні дисципліни, зокрема дисципліни самостійного вибору навчального закладу і дисципліни вільного вибору студента; місце і особливості проведення виробничої практики.

Основною професійною кваліфікацією, яка здобувається (присвоюється), переважно є викладач університетів та вищих навчальних закладів. Одноразово (по одній - в одній з програм) наводиться така кваліфікація: викладач вищого навчального закладу-тьютор; викладач вищого навчального закладуандрагог; викладач університетів та вищих навчальних закладів, тренер-коуч.

Метою визначено формування здатності застосовувати набуті знання, вміння, навички та розуміння 3 загальної та професійної підготовки для виконання освітніх, наукових завдань інноваційного характеру; розвиток їх здатностей до самостійної професійної діяльності у вищих навчальних закладах, наукових установах в галузі педагогіки на відповідній посаді, сфера застосування яких передбачена відповідно до "Класифікатора професій ДК 003:2010" [3]. Тільки за однією 3 програм метою є не тільки опанування загальних та фахових компетентностей, достатніх для комплексного вирішення проблем у професійнопедагогічній, інноваційній діяльності освітнього закладу, а і реалізації основних ідей освітнього коучингу.

Щодо придатності випускників до подальшого працевлаштування - існує достатнє різноманіття, яке дозволяє претендувати випускникам опановувати професії, що передбачають високий рівень знань у галузі фізичних, математичних, технічних, біологічних, агрономічних, медичних чи гуманітарних наук відповідно до переліку ДК 003:2010 видів економічної діяльності: викладач, викладачі університетів та вищих навчальних закладів, викладачі університетів та вищих навчальних закладів; інші викладачі університетів та вищих навчальних закладів, викладачі середніх навчальних закладів, інші професіонали в галузі навчання, професіонали в галузі методів навчання, наукові співробітники (методи навчання), інші професіонали в галузі методів навчання, інші професіонали в галузі навчання, інші наукові співробітники в галузі навчання, інші професіонали в галузі навчання; професійних назв робіт: асистент, викладач вищого навчального закладу, викладач професійного навчально-виховного закладу, викладач професійно-технічного навчального закладу, молодший науковий співробітник (методи навчання), науковий співробітник (методи навчання), науковий співробітник-консультант (методи навчання), викладач (методи навчання), методист, молодший науковий співробітник (в інших галузях навчання), науковий співробітник (в інших галузях навчання), науковий співробітник-консультант (в інших галузях навчання), лектор, педагог-організатор. Область професійної діяльності поширюється на: заклади освіти (університети, інститути, коледжі, професійно-технічні, заклади підвищення кваліфікації та післядипломної освіти та ін.); органи управління освітою та наукою; організації та виробництва, діяльність яких пов’язана з професійною підготовкою та перепідготовкою.

Серед вибіркових навчальних дисциплін, зокрема дисциплін самостійного вибору навчального закладу і дисциплін вільного вибору студента в одиничних випадках в освітніх програмах вказані такі дисципліни, прямо пов'язані або співпричетні з освітою дорослих: акмеологія, андрагогіка, педагогічна геронтологія, основи PR, тренінгова діяльність в освіті, коучингові технології в освіті, управління 
проектами в сфері освіти / моніторинг освітньої діяльності, медіапедагогіка, андрагогіка в системі педагогічних наук.

Професійна підготовка передбачає виробничу практику з практичної підготовки і стажування, як правило, на базі вищих навчальних закладів, рідше проведення практичних занять на базі університетських лабораторій чи в межах інших освітніх центрів чи проектів. Серед особливостей проведення виробничої практики вказується участь у комплексному тренінгу чи інших окремих професійних тренінгах - ораторського мистецтва, професійного самоусвідомлення, психології впливу, основ лідерства, психологічному тренінгу викладача тощо.

Здійснений нами аналіз освітньо-професійних програм другого (магістерського) рівня вищої освіти в галузі знань "01 Освіта" за спеціальністю "011 Науки про освіту" і "015 Професійна освіта" із спеціалізацією "Педагогіка вищої школи" показав відсутність цілеспрямованої практичної підготовки майбутніх науково-педагогічних працівників до педагогічної діяльності 3 дорослими як в умовах формальної, так і неформальної освіти. Водночас, наявні в окремих програмах змістові і структурні відмінності щодо включення окремих складових підготовки майбутніх науково-педагогічних працівників до фахової діяльності з дорослими свідчить про існування можливостей розширення змісту такої підготовки майбутніх науково-педагогічних працівників і наповненням дисциплінами, побудованими із врахуванням андрагогічної освітньої моделі.

Магістерську підготовку галузі знань "Освіта / Педагогіка" відповідно до П. 2.74 "Розподіл студентів університетів, академій, інститутів за галузями знань та спеціальностями, за якими здійснюється підготовка здобувачів вищої освіти, на початок 2017 / 18 навчального року" в Україні здійснювали 883 існуючих 289 закладів вищої освіти III-IV рівнів акредитації на початок 2017 / 18 навчального року університетів, академій, інститутів [4]. 3 них готують фахівців за спеціальністю "011 Науки про освіту" 47 закладів і 26 закладів - за спеціальністю "015 Професійна освіта". Здобувають другий (магістерський) рівень вищої освіти в Україні на початок 2017/18 навчального року за спеціальністю 011 - 1972 студенти, за спеціальністю 015 - 1713 студентів [4]. Усього магістерську підготовку в галузі знань "Освіта / Педагогіка" набувають на початок 2017 / 18 навчального року 32736 студентів [4]. Представлена статистика дає привід сподіватися на можливості озброєння майбутнього неформальної освіти дорослих потужним спеціально підготовленим фаховим персоналом.

Здійснене дослідження, узагальнення проаналізованих наукових, нормативно-правових джерел, спостереження, інтерв'ювання і бесіди 3 колегами дозволили встановити, що визнання значущості неформальної освіти дорослих, забезпечення ㄲï кваліфікованими кадрами, організація і здійснення спеціальної фахової підготовки майбутніх науково-педагогічних працівників дозволить сприяти адаптації дорослих до мінливих соціально-економічних змін, здобувати нові професії, запобігати конфліктам в життєдіяльності окремих спільнот і суспільства в цілому, допоможе маргінальним групам населення вирішувати їхні проблеми тощо.

Висновки та перспективи подальшого дослідження проблеми. Окреслена у статті проблема підготовки майбутніх науково-педагогічних працівників до фахової діяльності в умовах неформальної освіти дорослих потребує подальшого дослідження, розробки експериментальної освітньо-професійної програми і перевірки результатів ії впровадження.

\section{СПИСОК ВИКОРИСТАНИХ ДЖЕРЕЛ ТА ЛІТЕРАТУРИ}

1. Рассказова О. Л. Феномен неформальної освіти дорослих як педагогічної категорії / О. Л. Рассказова // Педагогіка формування творчої особистості у вищій і загальноосвітній школах : зб. наук. пр. [редкол.: T.I. Сущенко (голов. ред.) та ін.]. - Запоріжжя : КПУ, 2017. - Вип. 54 (107). - С. 203-212.

2. Про затвердження переліку посад педагогічних та науково-педагогічних працівників [Електронний ресурс] : Постанова Кабінету Міністрів України від 14 червня 2000 р. № 963. - Режим доступу : http://zakon1.rada.gov.ua/laws/show/963-2000-\%D0\%BF.

3. Класифікатор професій ДК 003:2010 [Електронний ресурс] : Наказ Держспоживстандарту України від 28 липня 2010 р. № 327 "Про затвердження, внесення змін та скасування нормативних документів". - Режим доступу : http://zakon.rada.gov.ua/rada/show/va327609-10.

4. Вища освіта в Україні у 2017 році : статистичний збірник. [Електронний ресурс] - К. : Державна служба $\begin{array}{llllll}\text { статистики } & \text { України, } 2018 . & - & 298 \text { c. } & & \end{array}$ http://www.ukrstat.gov.ua/druk/publicat/kat_u/publosvita_u.htm.

\section{REFERENCES (TRANSLATED \& TRANSLITERATED)}

1. Rasskazova O. L. Fenomen neformal'noi osvity doroslykh yak pedahohichnoi katehorii [The Phenomenon of NonFormal Adult Education as a Pedagogical Category] / O. L. Rasskazova // Pedahohika formuvannia tvorchoi osobystosti u vyshchii i zahalnoosvitnii shkolakh [Pedagogy of Creative Person's Formation in Higher and Secondary Schools] : [zb. nauk. pr.] / [redkol. : T. I. Sushchenko (holov. red.) ta in.]. - Zaporizhzhia : KPU, 2017. Vyp. 54 (107). - S. 203-212.

2. Pro zatverdzhennia pereliku posad pedahohichnykh ta naukovo-pedahohichnykh pratsivnykiv : Postanova Kabinetu Ministriv Ukrainy vid 14 chervnia 2000 r. № 963 [About the Approval of the List of Positions of Pedagogical and 
Scientific-Pedagogical Workers : the Resolution of the Cabinet of Ministers of Ukraine of June 14, 2000 No. 9]. Rezhym dostupu : http://zakon1.rada.gov.ua/laws/show/963-2000-\%D0\%BF.

3. Klasyfikator profesii DK 003:2010 : Nakaz Derzhspozhyvstandartu Ukrainy vid 28 lypnia 2010 r. № 327 "Pro zatverdzhennia, vnesennia zmin ta skasuvannia normatyvnykh dokumentiv" [Classifier of Professions DC 003 : 2010]. - Rezhym dostupu : http://zakon.rada.gov.ua/rada/show/va327609-10.

4. Vyshcha osvita v Ukraini u 2017 rotsi : statystychnyi zbirnyk [Higher Education in Ukraine in 2017 : Statistical Compendium]. - K. : Derzhavna sluzhba statystyky Ukrainy, 2018. - 298 s. - Rezhym dostupu: http://www.ukrstat.gov.ua/druk/publicat/kat_u/publosvita_u.htm.

\section{Самодумская Е. Л. Подготовка научно-педагогических работников к деятельности в неформальном образовании взросльх: реалии и перспективы.}

В статье охарактеризовань сущность, сочиальная и культурная значимость, особенности и ведущие функции современного неформального образования взросльх.

Обоснованны перспективы решения проблемы обеспечения неформального образования взросльх профессиональными кадрами благодаря организаџии спещиальной профессиональной подготовки будущих научно-педагогических работников в условиях магистратуры высших учебных заведений.

Ключевые слова: неформальное образование взросльх, научно-педагогические работники, образовательно-профессиональные программы.

\section{Samodumska O. L. Preparation of Scientific and Pedagogical Workers for Activities in Non-Formal Adult Education: Realities and Perspectives.}

The article identifies the problem of preparing future scientific and pedagogical workers for professional activity in the context of non-formal adult education.

The phenomenon of the rapid development of adult non-formal education and the important social and cultural significance of non-formal adult educations in solving various problems of social relations are characterized.

The leading functions of non-formal adult education, including the leading ones adaptation, information, compensatory, analytical, developing activity, are substantiated.

The present study provides that the solution to the need for non-formal education of adults by professional staff is possible thanks to the appropriate training of future scientific and pedagogical workers. For this purpose educational-professional programs of the second (master's) level of higher education in the field of knowledge "Education" are analyzed in the specialty "The science about education" and "Professional education" with the specialization "High school pedagogy" on the following indicators: qualification; the main focus of the program and specialization; the suitability of graduates for further employment; selective academic disciplines; place and features of production practice.

It is concluded that the problem of preparing scientific and pedagogical staff for pedagogical-teaching activity in non-formal adult education has the prospects for resolution and requires further research, development of an experimental educational-professional program with further diagnosis and correction of the results of its implementation.

Key words: non-formal adult education, scientific and pedagogical workers, educational and professional programs. 